\title{
Euploidy in somatic cells from R6/2 transgenic Huntington's disease mice
}

\author{
Åsa Petersén ${ }^{13}$, Ylva Stewénius², Maria Björkqvist² ${ }^{2}$ and David Gisselsson*2
}

Address: ${ }^{1}$ Neuronal Survival Unit, Department of Experimental Medical Science, Wallenberg Neuroscience Center, Lund University, Sweden, ${ }^{2}$ Department of Clinical Genetics, University Hospital, Lund, Sweden and ${ }^{3}$ Unit of Molecular Metabolism, Division of Diabetes, Metabolism, and Endocrinology, Department of Experimental Medical Science, Lund University, Sweden

Email: Åsa Petersén - asa.petersen@med.lu.se; Ylva Stewénius - ylva.stewenius@med.lu.se; Maria Björkqvist - maria.bjorkqvist@med.lu.se; David Gisselsson* - david.gisselsson@med.lu.se

* Corresponding author

Published: 13 September 2005

BMC Cell Biology 2005, 6:34 doi:10.1 I86/I47I-2I2I-6-34

This article is available from: http://www.biomedcentral.com/I47I-2/2I/6/34

This is an Open Access article distributed under the terms of the Creative Commons Attribution License (http://creativecommons.org/licenses/by/2.0), which permits unrestricted use, distribution, and reproduction in any medium, provided the original work is properly cited.

\begin{abstract}
Background: Huntington's disease (HD) is a hereditary neurodegenerative disorder caused by a CAG repeat expansion in the HD gene. The huntingtin protein expressed from $H D$ has an unknown function but is suggested to interact with proteins involved in the cell division machinery. The R6/ 2 transgenic mouse is the most widely used model to study HD. In R6/2 fibroblast cultures, a reduced mitotic index and high frequencies of multiple centrosomes and aneuploid cells have recently been reported. Aneuploidy is normally a feature closely connected to neoplastic disease. To further explore this unexpected aspect of HD, we studied cultures derived from 6- and 12week-old R6/2 fibroblasts, skeletal muscle cells, and liver cells.

Results: Cytogenetic analyses revealed a high frequency of polyploid cells in cultures from both R6/2 and wild-type mice with the greatest proportions of polyploid cells in cultures derived from skeletal muscle cells of both genotypes. The presence of polyploid cells in skeletal muscle in vivo was confirmed by fluorescence in situ hybridisation with centromeric probes. Enlarged and supernumerary centrosomes were found in cultures from both R6/2 and wild-type mice. However, no aneuploid cells could be found in any of the tissues.
\end{abstract}

Conclusion: We conclude that polyploid cells are found in fibroblast and skeletal muscle cultures derived from both $\mathrm{R} 6 / 2$ and wild-type littermate mice and that aneuploidy is unlikely to be a hallmark of HD.

\section{Background}

Huntington's disease (HD) is a hereditary neurodegenerative disorder caused by a CAG repeat expansion in the huntingtin gene [1]. It is characterized by personality changes, motor disturbances, cognitive decline, and weight loss [2]. Neuropathologically, the disease is reflected by neurodegeneration, primarily in the neostriatum, the cerebral cortex and the hypothalamus, with the appearance of cytoplasmic and intranuclear aggregates of misfolded huntingtin in neurons [3]. In HD patients and transgenic models of the disease, wild-type (wt) and mutant huntingtin are expressed in most tissues [4]. Neither the pathogenetic mechanism of HD nor the normal function of huntingtin is fully understood. Huntingtin interacts with key players of the mitotic machinery, such as the microtubuli and the centrosomes [5]. Interestingly, 
when huntingtin was identified in 1993 [1], one of its few known sequence motifs with established functions was the HEAT repeats [6]. These sequences are also found in proteins involved in mitotic progression and chromosomal dynamics [7]. The R6/2 transgenic mouse is the most widely used model to study HD. It expresses exon 1 of the human HD gene and displays several features of HD such as motor dysfunction, neuronal huntingtin aggregates, weight loss, and premature death at around 14 weeks of age [8]. In fibroblast cultures derived from R6/2 mice, a reduced mitotic index and high frequencies of cells with multiple centrosomes and aneuploidy have recently been reported [9]. Aneuploidy is characteristic for neoplastic cells, cells exposed to carcinogens, and cells from cancer-prone patients with hereditary chromosome instability syndromes. However, the phenomenon has rarely, if ever, been described in neurodegenerative disease in the absence of an increased risk for neoplasia. To further explore this unexpected aspect of HD, we have now performed extensive cytogenetic analyses of fibroblasts, skeletal muscle cells, and liver cells from 6- and 12week-old R6/2 and wt littermate mice. We found no evidence of aneuploidy in R6/2 cells, but a suprisingly high frequency of polyploid cells in cultures derived from both $\mathrm{R} 6 / 2$ and wt littermate mice.

Table I: Cytogenetic data.

\begin{tabular}{|c|c|c|c|c|c|c|c|c|c|}
\hline $\begin{array}{l}\text { Mouse } \\
\text { number }\end{array}$ & Biopsy site & $\begin{array}{l}\text { Passage } \\
\text { number }\end{array}$ & Ploidy $<2 n$ & Ploidy $=2 n$ & Ploidy $2 n-4 n$ & Ploidy $=4 n$ & Ploidy $>4 n$ & $\begin{array}{l}\text { Total } \\
\text { number of } \\
\text { cells } \\
\text { analyzed }\end{array}$ & $\begin{array}{l}\text { Polyp } \\
\text { cells }\end{array}$ \\
\hline \multicolumn{10}{|c|}{$\begin{array}{l}\text { Wild-type } \\
\text { week } 6\end{array}$} \\
\hline 30 & AM & 1 & 1 & 29 & 1 & 11 & 10 & 52 & 19 \\
\hline 31 & $\mathrm{PF}$ & I & 2 & 46 & 0 & 11 & 0 & 59 & 0 \\
\hline 31 & AM & I & I & 26 & 0 & 19 & 4 & 50 & 8.0 \\
\hline 31 & AM & 4 & 0 & 3 & 0 & 3 & 5 & 11 & 45 \\
\hline \multicolumn{10}{|c|}{$\begin{array}{l}\text { Wild-type } \\
\text { week I } 2\end{array}$} \\
\hline 76 & EL & 1 & 2 & 46 & 0 & 4 & 0 & 52 & 0 \\
\hline 76 & EL & 5 & 0 & 50 & 0 & 17 & 0 & 67 & 0 \\
\hline 76 & $\mathrm{PF}$ & 1 & 0 & 42 & 0 & 7 & 1 & 50 & 2.0 \\
\hline 76 & AM & 1 & 0 & 10 & 0 & I & I & 12 & 8.3 \\
\hline 77 & $\mathrm{EL}$ & 1 & 0 & 60 & 0 & 4 & 0 & 64 & 0 \\
\hline 77 & EL & 5 & 0 & 22 & 3 & 20 & 5 & 50 & 10 \\
\hline 77 & $\mathrm{EL}$ & I & 0 & 46 & 0 & 5 & I & 52 & 19 \\
\hline 77 & AM & I & 0 & 85 & 0 & 30 & 2 & 117 & 1.7 \\
\hline
\end{tabular}

R6/2 week

6

$\begin{array}{llllllllll}38 & \text { PF } & 1 & 0 & 45 & 0 & 5 & 0 & 50 & 0 \\ 38 & \text { AM } & 1 & 0 & 39 & 0 & 12 & 5 & 56 & 8.9 \\ 38 & \text { AM } & 4 & 0 & 32 & 0 & 32 & 1 & 65 & 1.5 \\ 38 & \text { LC } & 1 & 0 & 24 & 2 & 17 & 7 & 50 & 14 \\ 39 & \text { AM } & 1 & 0 & 33 & 1 & 12 & 4 & 50 & 8.0 \\ 39 & \text { AM } & 4 & 0 & 25 & 0 & 30 & 3 & 58 & 5.2\end{array}$

R6/2 week

12
78
78
78
78
79
79

$\begin{array}{llll}\text { EL } & 1 & 1 & 50 \\ \text { EL } & 5 & 0 & 39 \\ \text { PF } & 1 & 0 & 53 \\ \text { AM } & 1 & 0 & 30 \\ \text { PF } & 1 & 0 & 70 \\ \text { AM } & 1 & 0 & 50\end{array}$

50
39
53
30
70
50

0
1
0
1
1

4
19
3
4
7
7

$\begin{array}{lll}0 & 55 & 0 \\ 3 & 62 & 4.8 \\ 0 & 56 & 0 \\ 1 & 35 & 2.9 \\ 0 & 78 & 0 \\ 0 & 58 & 0\end{array}$

a Cells with a ploidy level above the tetraploid (4n). AM, abdominal muscle cells; PF, peritoneal fat fibroblasts; EL, ear lobe fibroblasts; LC, liver cells. 


\section{Results \\ Cytogenetic analysis}

Fresh biopsies were taken from ear lobes, abdominal skeletal muscles, peritoneal fat, and liver from sacrificed sixand 12-week-old mice (Table 1). Cells from R6/2 and wt littemate mice grew equally well in culture up to five passages, after which the culture process was terminated. Analysis of metaphase peritoneal fat fibroblasts, skeletal muscle cells, and liver cells from 6 -week-old R6/2 and wt littermate mice showed a normal diploid chromosome complement in the vast majority of cells and a tetraploid chromosome number in $3-32 \%$ of the cells. Cells taken from the abdominal skeletal muscle and the liver also showed $2-19 \%$ polyploid cells, with chromosome numbers up to the decaploid level ( $N=400$; Fig. 1a). These polyploid cells were present in biopsies both from R6/2 and wt mice. The highest frequencies were found in abdominal muscle biopsies from wt animals. After in vitro propagation up to four passages of muscle cells from one wt and two R6/2 mice, the frequency of polyploid cells had increased, compared to the first passage, from $8 \%$ to $45 \%$ in the wt culture, including cells with up to 600 chromosomes, whereas the frequency of such cells had decreased in one of the R6/2 cultures and was largely unchanged in the other. No more than four aneuploid cells were found in any of the cultures. These invariably showed loss of only one or two chromosomes compared to the diploid or tetraploid levels, or loss of up to four chromosomes compared to polyploid levels. In skeletal muscle cells, ear lobe fibroblasts, and peritoneal fat fibroblasts from 12-week-old animals, similar results were obtained. No more than four aneuploid cells (including hypodiploid, hypotetraploid, and hypopolyploid cells) were detected in any of the week-12 cultures.

\section{Centrosome morphology and mitotic polarity}

Centrosome detection was performed on cultured skeletal muscle cells, peritoneal fat fibroblasts, and ear lobe fibroblasts (passage 1 and also passage 5 of the ear lobe biopsies) from 12-week-old mice. This revealed abnormally enlarged centrosomes ( $>2$ centrioles) in a small population of cells in all cases $(1-4 \%)$. A proportion of these cells ( $0.5-2 \%$ out of all cells) had three or four centrosomes, whereas the remaining cells had normal centrosome numbers (one or two; Fig $1 \mathrm{~b}$ and 1c). There were no significant differences between wt and R6/2 cells ( $p>$ $0.05 ;>100$ cells analysed from each culture). Because supernumerary centrosomes have been associated with spindle multipolarity at mitosis, we also analysed cell division figures from the cultured biopsies of 6-week and 12-week mice after haematoxylin-eosin staining. Tripolar metaphase and anaphase configurations were detected in cells from the muscle biopsies from one of the 6 -week old R6/2 mice and one of the 6 -week old wt mice (2/160 cells and 2/232 cells respectively; Fig. 1d) but not in cells from any of the other biopsies ( $>150$ cells analysed per biopsy).

\section{Identification of polyploid cells in vivo}

In both R6/2 and wt mice, the highest rate of polyploidy was noted in cultures established from the abdominal muscle. To corroborate these findings in vivo and to identify the cell type harbouring an abnormally high chromosome number, $10 \mu \mathrm{m}$ tissue sections from two wt and two R6/2 mice were first examined after haematoxylin-eosin staining. This revealed a low frequency $(1-2 \%)$ of nuclei with diameters three to four times the normal range residing in the striated muscle fibres (Fig. 1e). Such enlarged nuclei were neither found in the adjacent fibrous tissue, nor in the vascular tissue penetrating the muscles. To exclude that these nuclei were simply artifacts caused by oblique cutting of the sections, fluorescence in situ hybridization (FISH) with a murine pan-centromeric probe was performed on muscle tissue sections from one wt mouse. As expected, this revealed two chromocenters in the majority of nuclei $(536 / 788=68 \%)$ and small populations of nuclei with one $(10 \%)$, three $(9 \%)$, or four $(9 \%)$ chromocenters. These signal configurations were also found in the adjacent fibrous tissues. However, there was also a small population (4\%) of large nuclei with seven or eight chromocenters (Fig. 1f), all of which were present in striated muscle fibres. Nuclei with $>4$ chromocenters were also found in abdominal muscle fibres from the other 12 week-old wt mouse and the two R6/2 mice, in proportions of $1-4 \%$.

\section{Discussion}

The function of normal huntingtin is not fully elucidated. Sequences of known functions within huntingtin include HEAT repeats, which are involved in chromosome dynamics [7]. In HD, the expanded polyglutamine in huntingtin is thought to alter its protein interactions [5]. A previous study described high frequencies of multiple centrosomes and aneuploidy in fibroblast lines derived from R6/2 mice and HD patients [9]. Aneuploidy is closely connected to neoplastic disease, as the vast majority of tumours exhibit acquired chromosome abnormalities [10]. Moreover, most inherited chromosome instability syndromes are associated with a significantly elevated risk of cancer. However, the risk of malignant tumours has been shown to be lower in HD patients than in the normal population [11]. To explore this ostensibly paradoxical situation, we performed cytogenetic analyses of cultured cells from multiple tissues in R6/2 mice. Although a high number of cells were analysed, we could find only minute populations of anueploid cells, occurring at similar frequencies in wt and R6/2 mice. These were typically hypodiploid, hypotetraploid, or hypopolyploid with loss of only few chromosomes, indicating that they were most probably due to artifactual loss of 

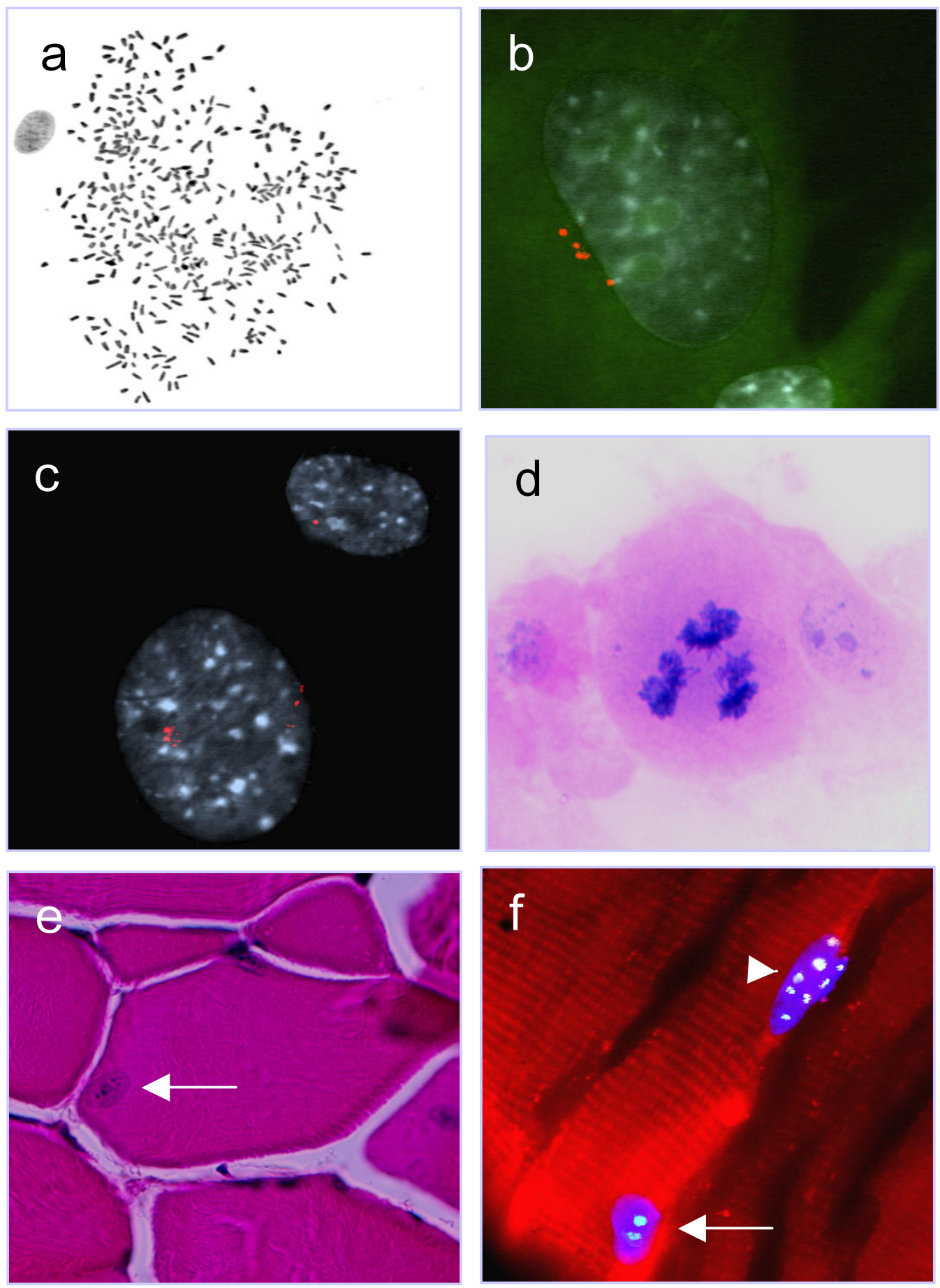

\section{Figure I}

Cytogenetic and immunofluorescent analysis. G-banded polyploid metaphase cell from wt3 I abdominal muscle (a). Multiple centrosomes (red) in cells from the peritoneal fat of R6/2 78 (b; green autofluorescence indicates cytoplasm) and from the abdominal muscle of wt77 (c; autofluorescence removed for clarity). Tripolar anaphase cell visualized by haematoxylin-eosin staining in a cell (passage I) from the abdominal muscle of wt30 (d). Large nucleus (arrow) in a skeletal muscle fibre from wt77 (e). One nucleus with two chromocenters (arrow; green) and one with eight chromocenters (arrowhead) in a skeletal muscle fibre from wt76 (f). 
chromosomes during preparation. Hence, we found no convincing evidence for aneuploidy. The reason for the discrepancy of results between our study and the previous report [9] may arise from differences in the genetic background of the R6/2 colonies, different culture procedures, or differences in the methods for chromosome preparation. Furthermore, in our study, we defined aneuploidy according to the ISCN (1995) recommendations [12], whereas the previous study defined aneuploid cells as any cells harboring a chromosome number different than $2 \mathrm{n}$ $=40$. Some of the cells scored as polyploid in our study might thus have been scored as "aneuploid" in the previous study by Sathasivam et al [9]. We found small populations of highly polyploid cells in liver, fibroblast and skeletal muscle cultures derived from R6/2 and wt littermate mice. In these cultures, derived from two mice per genotype, there was no difference in the frequency of polyploid cells between R6/2 and wt mice.

Polyploid cells have been found in several murine tissue including vascular smooth muscle [13], ovaries [14], cardiomyocytes [15], colonic fibroblasts [16], liver cells, bladder epithelial cells, uterine decidua cells, trophoblasts, and megakaryocytes [17]. Our study supports that polyploidy is a normally occurring phenomenon in many murine tissues and shows that skeletal muscle cells may have an unusually high frequency of polyploid cells. An earlier investigation describes a high frequency of multiple centrosomes in fibroblast cell lines from R6/2 mice and from HD patients [9]. In the present study, we found low frequencies of cells with multiple centrosomes in cultures from both R6/2 and wt littermate mice. In neoplastic cells, supernumerary centrosomes are associated with multi-polar cell divisions and have traditionally been suggested to generate aneuploid daughter cells [18]. Somewhat surprisingly, we found multipolar mitoses at a low frequency in skeletal muscle cultures from both genotypes. To our knowledge, this type of mitotic aberration has not been shown previously in non-neoplastic cells. Whether similar mitotic aberrations also occur in murine skeletal muscle in vivo remains to be established.

\section{Conclusion}

The present study shows that even though polyploidy may occur to a similar extent in wt and R6/2 cultured somatic cells, aneuploidy does not occur at a high frequency in R6/ 2 cells.

\section{Methods}

\section{Transgenic mice}

Transgenic HD mice of the R6/2 line were originally purchased from Jackson Laboratories (Bar Harbor, ME, USA) and the colony was maintained by breeding heterozygous R6/2 males with females from their background strain (F1 of $\mathrm{CBA} \times \mathrm{C} 57 \mathrm{Bl} / 6$ ). Tails of the offspring were used to obtain DNA for determination of the genotype using a polymerase chain reaction assay [8]. The mice exhibit around 150 CAG repeats in the exon 1 of the HD gene. The mice were housed in groups with ad libitum access to food and water at a $12 \mathrm{~h}$ light/dark cycle and sacrificed at either 6 or 12 weeks of age using halothane anaesthesia. The experimental procedures were approved by the Ethical Committee at Lund University.

\section{Cell culture and morphological analyses}

Cells were cultured in RPMI 1640 medium, supplemented with $17 \%$ bovine serum, glutamine, and antibiotics. Chromosome preparation, G-banding, analysis of mitotic morphology, haematoxylin-eosin staining, and FISH were performed according to standard methods [19]. The number of metaphase cells analyzed from each biopsy, genotype, and age are specified in Table 1. Mouse major satellite sequences were detected in at least 500 interphase nuclei per biopsy using commercially available probes (Cambio, Cambridge, UK). Centrosome morphology was visualized by immuno-fluorescence using a monoclonal anti- $\gamma$-tubulin antibody $(1: 1000$, GTU-88, Sigma, St. Louis, MS). At least 100 cells from each biopsy were analysed.

\section{List of abbreviations \\ FISH fluorescence in situ hybridization}

HD Huntington's disease

Wt wild-type

\section{Authors' contributions}

ÅP participated in the design of the study as well as the writing of the manuscript. YS carried out the cell culturing and the chromosome preparation. $\mathrm{MB}$ prepared the muscle tissue. DG performed the cytogenetic and FISH analyses and participated in the design of the study, and the writing of the manuscript.

\section{Acknowledgements}

We are grateful to Elsy Ling and Doris Persson for excellent technical assistance. ÅP and MB are supported by the Swedish Brain Foundation. YS and DG are supported by the Swedish Children's Cancer Foundation, the Sharon B. Lund Foundation of the American Cancer Society, and by the Donation Funds of the Lund University Hospital.

\section{References}

I. Huntington's Disease Collaborative Research Group: A novel gene containing a trinucleotide repeat that is expanded and unstable on Huntington's disease chromosomes. Cell 1993, 72:971-983.

2. Petersen $\AA$, Brundin P: Huntington's disease: the mystery unfolds? Int Rev Neurobiol 2002, 53:315-339.

3. DiFiglia M, Sapp E, Chase KO, Davies SW, Bates GP, Vonsattel JP, Aronin N: Aggregation of huntingtin in neuronal intranuclear inclusions and dystrophic neurites in brain. Science 1997, 277:1990-1993. 
4. Landles C, Bates GP: Huntingtin and the molecular pathogenesis of Huntington's disease. Fourth in molecular medicine review series. EMBO Rep 2004, 10:958-963.

5. Li SH, Li X]: Huntingtin-protein interactions and the pathogenesis of Huntington's disease. Trends Genet 2004, 20: I 46- I 54.

6. Andrade MA, Bork P: HEAT repeats in the Huntington's disease protein. Nat Genet 1995, I I:I I5- I I6.

7. Neuwald AF, Hirano T: HEAT repeats associated with condensins, cohesins, and other complexes involved in chromosome-related functions. Genome Res 2000, 10:1445-1452.

8. Mangiarini L, Sathasivam K, Seller M, Cozens B, Harper A, Hetherington C, Lawton M, Trottier Y, Lehrach H, Davies SW, Bates GP: Exon I of the HD gene with an expanded CAG repeat is sufficient to cause a progressive neurological phenotype in transgenic mice. Cell 1996, 87:493-506.

9. Sathasivam K, Woodman B, Mahal A, Bertaux F, Wanker EE, Shima DT, Bates GP: Centrosome disorganization in fibroblast cultures derived from R6/2 Huntington's disease (HD) transgenic mice and HD patients. Hum Mol Genet 2001, 1 0:2425-2435.

10. Mitelman F, Johansson B, Mertens F: Mitelman Database of Chromosome Aberrations in Cancer. 2005 [http://cgap.nci.nih.gov/ Chromosomes/Mitelman]

II. Sorensen SA, Fenger K, Olsen JH: Significantly lower incidence of cancer among patients with Huntington disease. Cancer 1999 , 86: $1342-1346$

12. Mitelman F, ed: An International System for Human Cytogenetic Nomenclature Basel: S. Karger; 1995.

13. Jones MR, Ravid K: Vascular smooth muscle polyploidization as a biomarker for aging and its impact on differential gene expression. J Biol Chem 2004, 279:5306-53 I 3.

14. Keighren M, West JD: Analysis of cell ploidy in histological sections of mouse tissues by DNA-DNA in situ hybridization with digoxigenin-labelled probes. Histochem J 1993, 25:30-44.

15. Brodsky VY, Delone GV, Tsirekidze NN: Genome multiplication in cardiomyocytes of fast- and slow-growing mice. Cell Differ 1985, I7:|75-181.

16. Neal JV, Potten CS: Polyploidy in the murine colonic pericryptal fibroblast sheath. Cell Tissue Kinet 198I, 14:527-536.

17. Keighren MA, Macfadyen LP, Hill AS, Patek CE, Telfer EE, West JD: Polyploid cells in the mouse ovary. J Anat 2003, 202:563-571.

18. Hansemannn D: Ueber patologische Mitosen. Arch Pathol Anat Phys Klin Med I89I, I I 9:299-326.

19. Gisselsson D, Jonson T, Yu C, Martins C, Mandahl N, Wiegant J, Jin $Y$, Mertens $F$, Jin C: Centrosomal abnormalities, multipolar mitoses, and chromosomal instability in head and neck tumours with dysfunctional telomeres. Br J Cancer 2002, 87:202-207.
Publish with Bio Med Central and every scientist can read your work free of charge

"BioMed Central will be the most significant development for disseminating the results of biomedical research in our lifetime. "

Sir Paul Nurse, Cancer Research UK

Your research papers will be:

- available free of charge to the entire biomedical community

- peer reviewed and published immediately upon acceptance

- cited in PubMed and archived on PubMed Central

- yours - you keep the copyright
BioMedcentral 